\title{
KUALITAS PELAPORAN KEUANGAN PADA USAHA BISNIS APOTEK DI KOTA DENPASAR
}

\author{
Ni Nyoman Ayu Suryandari ${ }^{1)}$ \\ Veronika Me'e ${ }^{2)}$ \\ ${ }^{1), 2)}$ Universitas Mahasaraswati, email:a.suryandari@ymail.com
}

\begin{abstract}
The existence of a pharmacy that has two functions, namely health services and business or companies are in dire need of financial statements. From the financial statements, the financial and economic conditions of a company or pharmacy can be known. This study aims to reexamine the influence of leadership ethics variables, internal audit function and level of understanding of accounting on the quality of financial reporting. The sample in this study were 35 people who worked as a maker of pharmacy financial statements in Denpasar City. Determination of the sample using purposive sampling method and the test equipment used is multiple linear regression analysis.

The results showed that the leadership ethics variable had no effect on the quality of financial reporting in the pharmacy business business as indicated by a significance value of 0.141 . The variable internal audit function does not affect the quality of financial reporting in the pharmacy business in Denpasar City which is indicated by a significance value of 0.281 , while the variable level of accounting understanding has a positive effect on the quality of financial reporting in the pharmacy business in Denpasar which is indicated by a significance value of 0.043 .
\end{abstract}

\section{Keywords: Ethics, Audit, Accounting, Financial Reporting}

\section{PENDAHULUAN}

Masalah-masalah yang timbul dalam perusahaan berdampak pada bidang keuangan. Baridwan (2004:17) dalam Intermediate Accounting, mendefinisikan laporan keuangan merupakan ringkasan suatu proses pencatatan dari transaksi-transaksi keuangan yang terjadi selama satu tahun buku yang bersangkutan. Berbeda dengan manajemen eksekutif, audit internal memiliki fungsi yang sangat penting bagi perusahaan yaitu melakukan kegiatan penilaian bebas yang terdapat dalam organisasi, yang dilakukan dengan cara menyajikan analisis penilaian, rekomendasi dan komentar-komentar penting terhadap kegiatan manajemen (Mulyadi). Pelaporan keuangan perusahaan merupakan hasil dari proses akuntansi yang bertujuan untuk mengukur dan mengungkapkan hasil audit, data kuantitatif 
terkait posisi keuangan dan performa perusahaan. Oleh karena laporan keuangan digunakan oleh para stakeholder dalam pengambilan keputusan, maka diperlukan laporan keuangan yang berkualitas. Pengungkapan atas pelaporan keuangan merupakan mekanisme yang paling efisien dan efektif untuk mendorong pimpinan perusahaan dalam melakukan pengelolaan. Keberadaan apotek mempunyai dua fungsi yaitu pelayanan kesehatan dan bisnis atau perusahaan (Umar, 2000). Secara teknis bisnis apotek membutuhkan manajemen khusus karena diferensiasi serta spesifikasi produk yang kuat pada produk kesehatan, khususnya obat. Manajemen apotek terdiri atas manajemen keuangan, manajemen persediaan, manajemen pembelian, manajemen pemasaran, manajemen penjualan. Seperti yang kita ketahui terdapat kasus yang terkait dengan Apotik yaitu kasus PT Kimia Farma Tbk yang memanipulasi laporan keuangannya pada tahun 2001 dimana mengandung unsur rekayasa dan penggelembungan. Laporan keuangan PT Kimia Farma Tbk per tanggal 31 Desember 2001 menyatakan laba bersih sebesar Rp 132 miliar dan telah diaudit oleh KAP Hans Tuanakotta dan Mustofa. Kementerian BUMN dan Bapepam menilai bahwa laba bersih tersebut terlalu besar dan mengandung unsur rekayasa sehingga pada tanggal 3 Oktober 2002 laporan keuangan PT Kimia Farma Tbk 2001 disajikan kembali dengan keuntungan hanya sebesar Rp 99,56 miliar. Dampak dari kasus ini antara lain adalah: PT Kimia Farma Tbk melaporkan overstated laporan keuangan tahun 2001, pemakai laporan keuangan salah dalam pengambilan keputusan, citra dan reputasi auditor menurun. Penyelesaian kasus sesuai Pasal 102 Undang-undang Nomor 8 Tahun 1995 tentang pasar modal yaitu Direksi lama PT Kimia Farma Tbk periode 1998-2002 diwajibkan membayar Rp 1 miliar untuk disetor ke kas negara karena melakukan kegiatan praktek penggelembungan atas laporan keuangan tahun 2001, saudara Ludovicus Sensi W rekan KAP Hans Tuanakotta dan Mustofa selaku auditor PT Kimia Farma Tbk diwajibkan 
membayar sejumlah Rp 100 juta rupiah untuk disetor ke kas negara karena atas risiko audit yang tidak berhasil mendeteksi adanya penggelembungan laba yang dilakukan oleh PT Kimia Farma Tbk. Sesuai ilustrasi pada kasus PT Kimia Farma Tbk maka penelitian ini menjadi menarik untuk dilakukan kembali pada usaha bisnis apotek di Kota Denpasar.

Untuk menghindari adanya kasus manipulasi dalam laporan keuangan maka dalam menjalankan usahanya, perusahaan memerlukan seorang pemimpin yang beretika. Etika seorang pemimpin merupakan suatu hal yang penting. Seorang karyawan akan selalu melihat dan mencontoh atasannya. Ketika atasannya memiliki etika yang baik maka karyawannya akan meniru etika yang baik dari atasannya. Penelitian terkait etika kepemimpinan menghasilkan hal yang berbeda dimana Nudilah (2016) menyatakan bahwa etika kepemimpinan tidak berpengaruh terhadap kualitas pelaporan keuangan, sedangkan Putra (2013), Arel et al., (2013) serta Rifa'I (2014) membuktikan bahwa kepemimpinan etis berpengaruh positif terhadap kualitas laporan keuangan.

Selain etika kepemimpinan, pemahaman akuntansi oleh pembuat laporan keuangan dan juga upaya mendeteksi salah saji oleh internal audit sangatlah diperlukan. Dengan adanya pemahaman, kecerdasan atau pengetahuan yang baik terkait dengan akuntansi maka kualitas pelaporan keuangan suatu perusahaan itu dapat ditingkatkan dan mengurangi risiko salah saji (Nudilah, 2016). Penelitian yang pernah dilakukan oleh Diani (2014), Iswara (2013), Purwati dan Wasman (2014), serta Windiastuti (2013) memperoleh hasil dimana tingkat pemahaman akuntansi berpengaruh positif terhadap kualitas pelaporan keuangan. Dengan adanya audit internal, maka akan lebih mampu untuk mengurangi adanya risiko salah saji baik yang disengaja maupun yang tidak disengaja oleh para penyusun laporan keuangan. 
Salah satu faktor penentu kesuksesan di suatu organisasi adalah kepemimpinan. Kepemimpinan didefinisikan oleh Robbins (2006:432) sebagai kemampuan untuk mempengaruhi kelompok menuju pencapaian sasaran. Menurut Hasibuan (2009:12) kepemimpinan dapat dirumuskan sebagai berikut: Kepemimpinan menekankan adanya hubungan dua pihak yaitu pemimpin dan yang dipimpin atau pengikut, terjadi pola interaksi di antara pemimpin dengan pengikut, dalam pola interaksi yang terjadi di antara pemimpin mempengaruhi perilaku para pengikut, proses pemimpin mempengaruhi pengikutnya ini dilakukan agar para pengikut melakukan tindakan-tindakan untuk mencapai tujuan yang diharapkan oleh pemimpin atau tujuan yang telah disepakati bersama oleh pemimpin dan pengikutnya, tujuan yang ingin dicapai oleh pemimpin dan pengikutnya ialah tujuan organisasi. Berdasarkan definisi-definisi yang telah dikemukakan oleh para ahli, maka dapat disimpulkan bahwa kepemimpinan adalah suatu kegiatan yang dilakukan oleh seseorang kepada satu atau sekelompok orang dimana seseorang tersebut mampu mempengaruhi orang lain dengan maksud untuk mencapai suatu tujuan atau sasaran tertentu.

Selain berhubungan dengan kepemimpinan, penelitian ini juga terkait dengan teori kelembagaan atau instutional theory yang dapat didefinisikan sebagai teori yang menjelaskan tentang bagaimana suatu perusahaan berkembang dan bertahan ketika berada dalam lingkungan yang kompetitif yang penuh dengan para pesaing, serta mempelajari bagaimana cara perusahaan untuk memuaskan stakeholder (Widyawati, 2012). Terdapat dua teori yang berkaitan dengan teori kelembagaan ini yaitu teori kelembagaan lama (old institutional theory) dan teori kelembagaan baru (new institutional theory). Old institutional theory menurut Burn (dikutip oleh Widyawati, 2012) digunakan untuk menjelaskan mengapa dan bagaimana sesuatu dapat terjadi dan berlangsung dalam waktu yang lama dalam suatu organisasi, objek analisis dalam teori kelembagaan lama adalah individu 
sedangkan pada teori kelembagaan baru objek analisisnya adalah organisasi, sehingga dalam penelitian ini menggunakan new institutional theory (teori kelembagaan baru) karena yang diteliti adalah karakter orang-orang yang bertanggung jawab dalam pembuatan laporan keuangan yaitu etika yang di miliki oleh pemimpin, fungsi audit internal dan tingkat pemahaman akuntansi dari karyawan yang membuat laporan keuangan.

Penelitian ini mencoba untuk mengkaji pengaruh etika kepemimpinan, pemahaman akuntansi dan fungsi audit internal terhadap kualitas pelaporan keuangan pada usaha bisnis apotik di Kota Denpasar. Berdasarkan latar belakang yang disajikan diatas, tujuan dari penelitian ini adalah untuk menguji dan memperoleh bukti empiris pengaruh etika kepemimpinan, tingkat pemahaman akuntansi dan fungsi audit internal terhadap kualitas pelaporan keuangan pada usaha bisnis apotek di Kota Denpasar.

Seorang pemimpin harus menyatukan berbagai keahlian dengan pengalaman, kepribadian dan motivasi setiap individu yang dipimpinnya. Menurut Arel et al., (2012), dilema etika umum terjadi bagi karyawan tingkat yang lebih rendah dalam bisnis. Bagaimana tidak, dalam organisasi bawahan akan selalu menerima perintah dari atasannya dan terkadang akan menimbulkan dilema etika. Ketika atasan mereka meminta para karyawan tersebut untuk melakukan tindakan yang tidak etis seperti misalnya adalah memanipulasi laporan keuangan, maka karyawan yang merupakan bawahan tersebut akan cenderung untuk mengikuti perintah atasan, walaupun hal tersebut sebenarnya bertentangan dengan norma dan etika yang ada di masyarakat. Berdasarkan uraian tersebut, maka hipotesis pertama yang diajukan di dalam penelitian ini adalah sebagai berikut:

\section{H1$_{1}$ : Etika kepemimpinan berpengaruh positif terhadap kualitas pelaporan keuangan pada usaha bisnis apotek di Kota Denpasar.}


Pemahaman akuntansi adalah salah satu faktor penting dalam penyediaan laporan keuangan yang berkualitas. Pendidikan akuntansi akan mendidik mahasiswanya untuk memiliki pengetahuan dibidang akuntansi. Dengan adanya kecerdasan atau pengetahuan tentang akuntansi yang baik maka kualitas pelaporan keuangan suatu perusahaan itu akan dapat ditingkatkan dan terhindar dari adanya risiko salah saji (Nudilah, 2016). Dalam membuat pelaporan keuangan seorang akuntan harus memahami isi dalam laporan tersebut agar dapat mengerti dan mengambil keputusan dalam pelaporan keuangan. Berdasarkan uraian diatas, maka hipotesis kedua yang dikembangkan dalam penelitian ini adalah:

\section{H2: Tingkat pemahaman akuntansi berpengaruh positif terhadap kualitas pelaporan keuangan pada usaha bisnis apotek di Kota Denpasar.}

Kualitas pelaporan keuangan juga terkait dengan Sistem Pengandalian Intern dalam perusahaan. Sistem Pengendalian Intern berfungsi untuk mengawasi tugas dan fungsi masing-masing unit bagian sehingga setiap unit bagian memiliki tugas dan wewenang masing-masing (Suryandari dan Novitasari, 2016: 795). Salah satu dari Sistem Pengendalian Intern dalam perusahaan adalah fungsi dari audit internal. Menurut Arel et al., (2012) kekuatan atau kualitas pada fungsi audit internal akan memberikan kontribusi bagi lingkungan pengendalian dalam suatu organisasi. Auditor internal merupakan pihak yang membantu perusahaan untuk memastikan bahwa pengendalian internal pada laporan keuangan berjalan secara efektif tanpa terdapat kecurangan sehingga dapat diperoleh laporan keuangan yang dapat diandalkan. Sehingga dapat disimpulkan jika terdapat fungsi audit internal yang baik maka tindakan-tindakan yang kurang etis dalam perusahaan saat membuat laporan keuangan dapat terdeteksi sehingga akan dapat menjaga kualitas laporan keuangan.

Berdasarkan uraian tersebut, maka hipotesis ketiga yang diajukan di dalam penelitian ini adalah sebagai berikut: 


\section{H3: Fungsi audit internal berpengaruh positif terhadap kualitas pelaporan keuangan pada usaha bisnis apotek di Kota Denpasar.}

\section{METODE PENELITIAN}

\section{Rancangan penelitian}

Rancangan penelitian ini dimulai dengan adanya latar belakang penelitian yang mengandung masalah penelitian. Dengan mengkaji Grand Theory yaitu teori kepemimpinan dan teori kelembagaan lama dan kajian empiris maka dibangunlah hipotesis penelitian yang diuji dengan menggunakan analisis regresi linear berganda. Hasil pengujian dan kesimpulan penelitian kemudian akan dibandingkan dengan hipotesis penelitian dan apakah hasil penelitian tersebut telah mampu menjawab semua rumusan masalah penelitian.

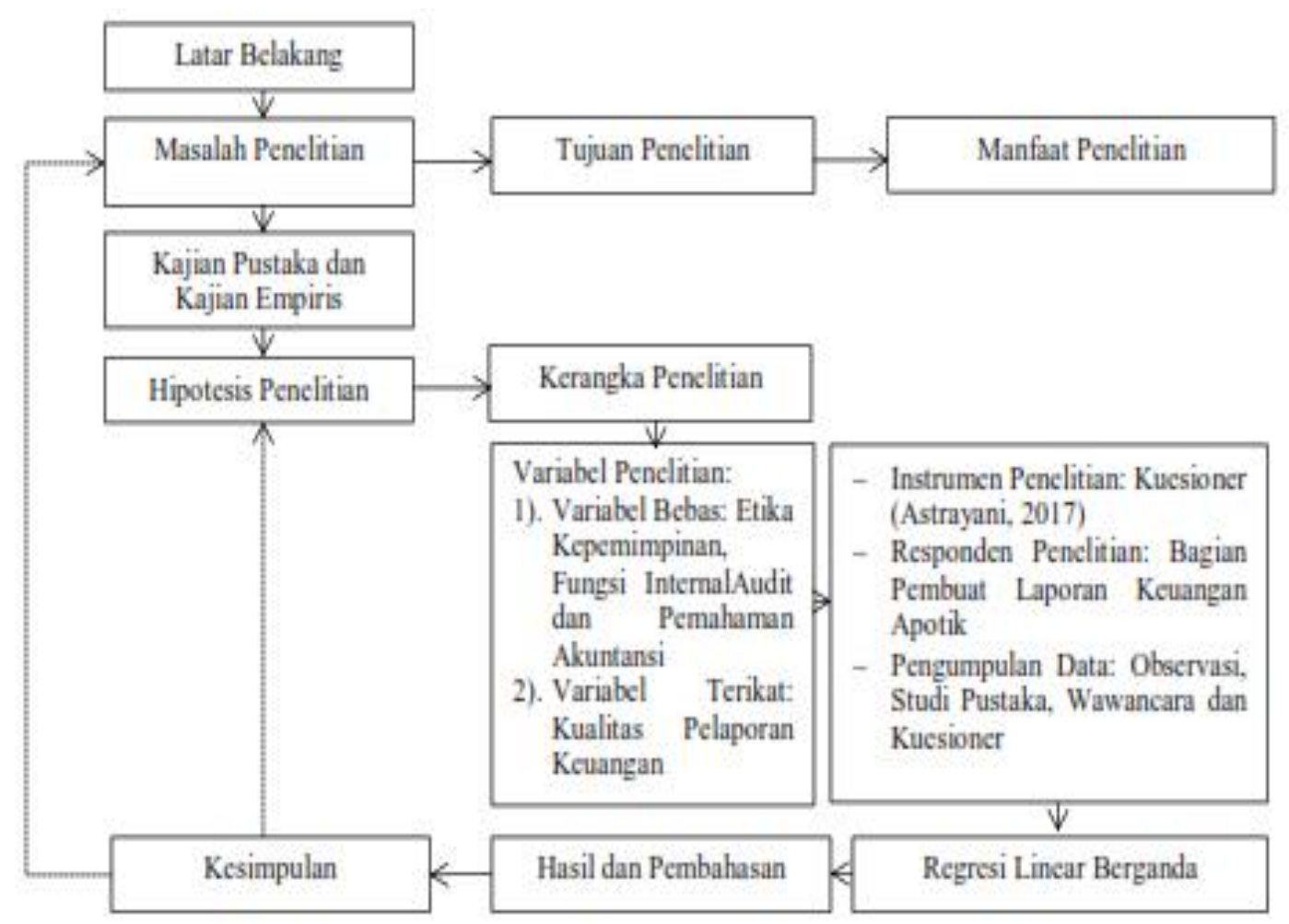

Gambar 1. Rancangan Penelittan

Sumber: Suryandari \& Me'e (2018) 


\section{Populasi dan sampel}

Populasi didalam penelitian ini adalah apotek yang terdapat di Kota Denpasar yang memiliki laporan keuangan sesuai standar akuntansi yang berlaku dan memiliki audit internal. Peneliti menemukan bahwa terdapat 8 (delapan) apotek pada 4 (empat) kecamatan di Kota Denpasar yang memiliki laporan keuangan sesuai standar akuntansi yang berlaku dan audit internal. Metode pengambilan sampel dalam penelitian ini menggunakan purposive sampling. Responden dalam penelitian ini adalah karyawan pembuat laporan keuangan yang bekerja minimal satu tahun. Dari 8 (delapan) apotek yang memiliki laporan keuangan sesuai standar akuntansi dan audit internal di Kota Denpasar terdapat 35 (tiga puluh lima) orang karyawan sebagai pembuat laporan keuangan.

\section{Tabel 1. Responden Penelitian}

\begin{tabular}{|c|c|c|c|}
\hline Nama Apotek & Alamat & $\begin{array}{c}\text { Jumlah } \\
\text { Accounting }\end{array}$ & $\begin{array}{l}\text { Keterangan } \\
\text { Sub Bagian }\end{array}$ \\
\hline Anugerah 1 & Jl. Patimura no. 57 & 1 & 1) Ka.tim \\
\hline Anugerah 11 & Jl. Gatot Subroto no.1/2A & 1 & apotek \\
\hline Bhakti Rahayu & Jl. Gatot Subroto II/11 & 21 & 2) $\mathrm{Ka}$. \\
\hline K24 Monang Maning & Jl. Rinjani blok II A no.4 & 1 & keuangan apotek \\
\hline K24 Sesetan & Jl. Raya Sesetan no.222 & 1 & 3) Pelaksanan keuangan \\
\hline K24 Teuku Umar & Jl. Teuku Umar 170 B & 2 & apotek \\
\hline K24 Nangka & Jl. Nangka Utara no.282 & 1 & 4) Pelaksana pelayanan \\
\hline Quantum & Jl. Raya Sesetan no. 20 & 7 & $\begin{array}{l}\text { dan keuangan harian } \\
\text { apotek }\end{array}$ \\
\hline
\end{tabular}

Sumber: Dinas Perijinan PTSP dan Penanaman Modal Kota Denpasar, data diolah (2018)

\section{Teknik pengumpulan data}

Teknik yang dilakukan dalam penelitian ini adalah dengan menggunakan observasi, wawancara, kuesioner dan studi pustaka. Kuesioner dalam penelitian ini diadopsi dari kuesioner Astrayani (2017) dengan menggunakan 7 pertanyaan dan 5 skala likert. 


\section{Kerangka Penelitian}

Dalam menunjang kualitas laporan keuangan yang baik, terdapat beberapa faktor yang mempengaruhi, yaitu etika kepemimpinan, fungsi audit internal dan tingkat pemahaman akuntansi. Etika kepemimpinan merupakan cara pemimpin dapat memimpin pengikutnya dengan tetap mengindahkan kaidah nilai, dan norma yang berlaku di masyarakat. Fungsi audit internal merupakan pihak yang membantu perusahaan untuk memastikan bahwa pengendalian internal pada laporan keuangan berjalan secara efektif tanpa terdapat kecurangan sehingga dapat diperoleh laporan keuangan yang akurat yang disajikan. Fungsi audit internal yaitu dalam pelaksanaannya diharapkan mampu mengidentifikasi dan mengevaluasi risiko signifikan dan memberikan konstribusi terhadap peningkatan pengelolaan risiko dan sistem pengendalian intern. Tingkat pemahaman akuntansi merupakan sesuatu yang sangat diperlukan dalam penyusunan laporan itu sendiri. Dengan adanya kecerdasan atau pengetahuan tentang akuntansi yang baik maka kualitas pelaporan keuangan akan terhindar dari adanya kesalahan-kesalahan informasi yang dikarenakan kurangnya pengetahuan tentang pemahaman akuntansi.

Uraian di atas dapat dituangkan dalam kerangka penelitian sebagai berikut:

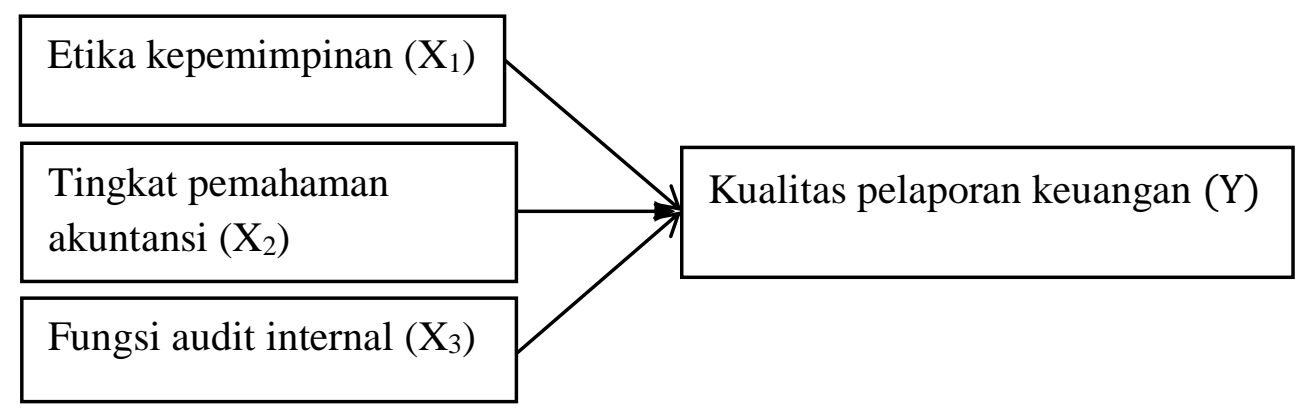

Gambar 2. Kerangka Penelitian

Sumber: Suryandari dan Me'e (2018) 


\section{Teknik Analisis Data}

Pengujian hipotesis dilakukan dengan menggunakan analisis regresi linear berganda dan diuji dengan tingkat signifikansi 0,05. Adapun persamaan regresi linear berganda yang dipergunakan adalah:

$$
\begin{array}{ll}
\mathrm{Y}=\mathrm{a}+\beta 1 \mathrm{ETIKA}+\beta 2 \mathrm{FAI}+\beta 3 \mathrm{TPA}+\ldots \ldots \ldots \ldots . . . . \\
\mathrm{KPK} & =\text { Kualitas Pelaporan Keuangan } \\
\mathrm{a} & =\text { Konstanta } \\
\text { ETIKA } & =\text { Etika Kepemimpinan } \\
\text { FAI } & =\text { Fungsi Audit Internal } \\
\text { TPA } & =\text { Tingkat Pemahaman Akuntansi } \\
\beta 1, \beta 2, \beta 3 & =\text { Koefisien Regresi } \\
\mathrm{e} & =\text { Standar Error }
\end{array}
$$

\section{HASIL DAN ANALISIS}

\section{Statistik deskriptif}

Tabel 2 menampilkan hasil dari statistik deskriptif untuk masing-masing variabel dalam penelitian ini.

\section{Tabel 2. Statistik Deskriptif}

\begin{tabular}{lccccc}
\hline & N & Minimum & Maximum & Mean & $\begin{array}{c}\text { Std. } \\
\text { Deviation }\end{array}$ \\
\hline Etika Kepemimpinan & 35 & 27,00 & 35,00 & 31,2000 & 2,28550 \\
$\begin{array}{l}\text { Fungsi Audit Internal } \\
\text { Tingkat Pemahaman }\end{array}$ & 35 & 27,00 & 35,00 & 31,2000 & 2,74183 \\
$\begin{array}{l}\text { Akuntansi } \\
\text { Kualitas }\end{array} \quad$ Pelaporan & 35 & 23,00 & 35,00 & 30,1714 & 3,33860 \\
Keuangan & & & & & \\
Valid N (Listwise) & 35 & & 35,00 & 32,0286 & 3,15749 \\
\hline
\end{tabular}

Sumber: Data diolah (2018) 


\section{Uji instrumen}

Uji validitas

Tabel 3. Hasil Uji Validitas

\begin{tabular}{|c|c|c|c|c|}
\hline No & Variabel & Instrumen & Koefisien Korelasi & Keterangan \\
\hline \multirow[t]{7}{*}{1} & Etika & $X_{1.1}$ & 0,720 & Valid \\
\hline & kepemimpinan & $\mathrm{X}_{1.2}$ & 0,579 & Valid \\
\hline & $\left(\mathrm{X}_{1}\right)$ & $\mathrm{X}_{1.3}$ & 0,681 & Valid \\
\hline & & $X_{1.4}$ & 0,447 & Valid \\
\hline & & $X_{1.5}$ & 0,352 & Valid \\
\hline & & $X_{1} .6$ & 0,642 & Valid \\
\hline & & $X_{1.7}$ & 0,631 & Valid \\
\hline \multirow[t]{7}{*}{2} & Fungsi audit & $\mathrm{X}_{2.1}$ & 0,654 & Valid \\
\hline & internal $\left(\mathrm{X}_{2}\right)$ & $\mathrm{X}_{2 .} .2$ & 0,646 & Valid \\
\hline & & $\mathrm{X}_{2.3}$ & 0,665 & Valid \\
\hline & & $X_{2.4}$ & 0,708 & Valid \\
\hline & & $X_{2.5}$ & 0,599 & Valid \\
\hline & & $X_{2} .6$ & 0,641 & Valid \\
\hline & & $X_{2.7}$ & 0,708 & Valid \\
\hline \multirow[t]{7}{*}{3} & Tingkat & $\mathrm{X}_{3.1}$ & 0,806 & Valid \\
\hline & pemahaman & $\mathrm{X}_{3.2}$ & 0,734 & Valid \\
\hline & akuntansi $\left(\mathrm{X}_{3}\right)$ & $\mathrm{X}_{3.3}$ & 0,737 & Valid \\
\hline & & $\mathrm{X}_{3.4}$ & 0,770 & Valid \\
\hline & & $X_{3.5}$ & 0,774 & Valid \\
\hline & & $X_{3} .6$ & 0,735 & Valid \\
\hline & & $X_{3.7}$ & 0,714 & Valid \\
\hline \multirow[t]{7}{*}{4} & Kualitas & Y.1 & 0,760 & Valid \\
\hline & pelaporan & Y.2 & 0,855 & Valid \\
\hline & keuangan (Y) & Y.3 & 0,712 & Valid \\
\hline & & Y.4 & 0,814 & Valid \\
\hline & & Y.5 & 0,875 & Valid \\
\hline & & Y.6 & 0,896 & Valid \\
\hline & & Y.7 & 0,838 & Valid \\
\hline
\end{tabular}

Sumber : data diolah (2018)

Berdasarkan data hasil uji dapat diketahui bahwa semua nilai koefisien korelasinya diatas 0,3 maka semua instrumen dikatakan valid.

Uji realiabilitas

\section{Tabel 4. Hasil uji realiabilitas}

\begin{tabular}{lcc}
\hline Variabel & Alpha Cronbach & Keterangan \\
\hline Etika kepemimpinan $\left(\mathrm{X}_{1}\right)$ & 0,723 & Reliabel \\
Fungsi audit internal $\left(\mathrm{X}_{2}\right)$ & 0,760 & Reliabel \\
\hline
\end{tabular}




\begin{tabular}{lll}
\hline Tingkat pemahaman akuntansi $\left(\mathrm{X}_{3}\right)$ & 0,860 & Reliabel \\
Kualitas pelaporan keuangan $(\mathrm{Y})$ & 0,913 & Reliabel \\
\hline
\end{tabular}

Sumber: data diolah (2018)

Berdasarkan data hasil uji semua instrumen koefisien cronbach alpha $>0,7$ maka semua item pertanyaan dikatakan reliabel.

\section{Uji asumsi klasik}

Uji normalitas

\section{Tabel 5. Hasil uji normalitas}

\begin{tabular}{llc}
\hline & & $\begin{array}{c}\text { Unstandardized } \\
\text { Residual }\end{array}$ \\
\hline $\mathrm{N}$ & & 35 \\
Normal Parameters & Mean & 0,0000000 \\
& Std. Deviation & 2,77862468 \\
Most Extreme & Absolute & 0,118 \\
Differences & Positive & 0,082 \\
& Negative & $-0,118$ \\
Kolmogorov Smirnov Z & & 0,697 \\
Asymp. Sig (2-tailed) & & 0,716 \\
\hline
\end{tabular}

Sumber: data diolah (2018)

Berdasarkan hasil pengolahan data diperoleh besarnya nilai Kolmogorov-Smirnov adalah 0,697 dan signifikansi pada 0.716 yang lebih besar dari 0,05 maka data residual berdistribusi normal.

Uji Multikolinieritas

Tabel 6.Hasil uji multikolinieritas

\begin{tabular}{cccc}
\hline & & \multicolumn{2}{c}{ Collinearity Statistics } \\
Tolerance & VIF \\
Model & & & \\
\hline & (Constant) & & \\
ETIKA & 0,652 & 1.534 \\
& FAI & 0,700 & 1.428 \\
TPA & 0,908 & 1.102 \\
\hline Sumber: data diolah (2018) & & \\
\hline
\end{tabular}


Berdasarkan Tabel 6 dapat diketahui bahwa nilai masing-masing variabel memiliki nilai VIF di bawah 10 dan nilai tolerance di atas 0,1 sehingga dapat disimpulkan bahwa tidak terjadi hubungan multikolinieritas antara variabel independen.

Uji heteroskedastisitas

Tabel 7. Hasil uji heteroskedastisitas

\begin{tabular}{|c|c|c|c|c|c|}
\hline \multirow[t]{2}{*}{ Model } & \multicolumn{2}{|c|}{$\begin{array}{l}\text { Unstandardized } \\
\text { Coefficients }\end{array}$} & \multirow{2}{*}{$\begin{array}{c}\text { Standardized } \\
\text { Coefficients } \\
\text { Beta }\end{array}$} & \multirow[t]{2}{*}{$\mathbf{t}$} & \multirow[t]{2}{*}{ Sig } \\
\hline & B & $\begin{array}{l}\text { Std. } \\
\text { Error }\end{array}$ & & & \\
\hline (Constant) & 12,597 & 4,092 & & 3,078 & 0,004 \\
\hline ETIKA & $-0,100$ & 0,144 & $-0,139$ & $-0,690$ & 0,495 \\
\hline FAI & $-0,114$ & 0,116 & $-0,190$ & $-0,978$ & 0,336 \\
\hline TPA & $-0,124$ & 0,084 & $-0,252$ & $-1,479$ & 0,149 \\
\hline
\end{tabular}

Sumber: data diolah (2018)

Hasil pengujian heteroskedastisitas menunjukan nilai probabilitas signifikansi masing-masing variabel bebas lebih besar dari 0,05, sehingga dapat disimpulkan bahwa model regresi dalam penelitian ini bebas dari heterokedastisitas.

\section{Analisis regresi linear berganda}

Tabel 8. Hasil uji regresi linear berganda

\begin{tabular}{|c|c|c|c|c|c|c|c|}
\hline \multirow{2}{*}{ Model } & \multicolumn{2}{|c|}{$\begin{array}{l}\text { Unstandardized } \\
\text { Coefficients }\end{array}$} & \multirow{2}{*}{$\begin{array}{c}\text { Standardized } \\
\text { Coefficients } \\
\text { Beta }\end{array}$} & \multirow[t]{2}{*}{$\mathbf{t}$} & \multirow[t]{2}{*}{ Sig } & \multicolumn{2}{|c|}{$\begin{array}{l}\text { Collinearity } \\
\text { Statistics }\end{array}$} \\
\hline & B & $\begin{array}{l}\text { Std. } \\
\text { Error }\end{array}$ & & & & Tolerance & VIF \\
\hline (Constant) & 16,750 & 7,668 & & 2,184 & 0,037 & & \\
\hline ETIKA & 0,409 & 0,270 & 0,296 & 1,511 & 0,141 & 0,652 & 1,534 \\
\hline FAI & $-0,239$ & 0,217 & $-0,207$ & $\begin{array}{c}- \\
1,097\end{array}$ & 0,281 & 0,700 & 1,428 \\
\hline TPA & 0,331 & 0,157 & 0,350 & 2,107 & 0,043 & 0,908 & 1,102 \\
\hline
\end{tabular}

Sumber: data diolah (2018)

Persamaan regresi linear berganda adalah sebagai berikut:

$\mathrm{Y}=16,750+0,409 \mathrm{ETIKA}-0,239 \mathrm{FAI}+0,331 \mathrm{TPA}$ 


\section{Uji kelayakan model ( Goodness of fit model )}

Koefisien korelasi $(\mathrm{R})$ dan koefisien determinasi $\left(\mathrm{R}^{2}\right)$

Tabel 9.Hasil uji kelayakan model

\begin{tabular}{lllll}
\hline Model & $\mathbf{R}$ & $\begin{array}{l}\mathbf{R} \\
\text { Square }\end{array}$ & Adjusted R Square & Std. Error of the Estimate \\
\hline 1 & 0,475 & 0,226 & 0,151 & 2,90997 \\
\hline
\end{tabular}

Sumber: data diolah (2018)

Berdasarkan Tabel 9 diperoleh angka R (koefisien korelasi) sebesar 0,475. Hal ini menunjukkan bahwa adanya korelasidengan nilai sedang antara etika kepemimpinan, fungsi audit internal dan tingkat pemahaman akuntansi terhadap kualitas pelaporan keuangan. Sedangkan nilai adjusted $R$ Square menunjukkan bahwa prosentase sumbangan pengaruh variabel independen terhadap variabel dependen adalah sebesar 0,151 $(15,1 \%)$.

Uji F

Tabel 10. Hasil uji F

\begin{tabular}{|c|c|c|c|c|c|}
\hline Model & $\begin{array}{l}\text { Sum } \\
\text { Squares }\end{array}$ & df & $\begin{array}{l}\text { Mean } \\
\text { Square }\end{array}$ & $\mathbf{F}$ & Sig. \\
\hline Regression & 76,466 & 3 & 25,489 & 3,010 & 0,045 \\
\hline Residual & 262,506 & 31 & 8,468 & & \\
\hline Total & 338,971 & 34 & & & \\
\hline
\end{tabular}

Sumber: data diolah (2018)

Berdasarkan hasil uji diperoleh F hitung 3,010 dengan signifikansi 0,045 lebih kecil dari 0,05. Dengan demikian, persamaan model regresi ini bersifat fit atau layak digunakan.

\section{PEMBAHASAN}

Pengaruh etika kepemimpinan terhadap kualitas pelaporan keuangan pada usaha bisnis apotek di Kota Denpasar. Hipotesis pertama menyatakan bahwa etika kepemimpinan berpengaruh positif terhadap kualitas pelaporan keuangan pada usaha bisnis apotek di Kota Denpasar. Hasil uji regresi menunjukan bahwa variabel etika kepemimpinan memiliki nilai koefisien sebesar 0,409 dengan nilai signifikan sebesar 0,141 lebih besar dari 
0,05 sehingga $\mathrm{H}_{1}$ ditolak, yang berarti bahwa etika kepemimpinan tidak berpengaruh terhadap kualitas pelaporan keuangan pada usaha bisnis apotek di Kota Denpasar. Hasil temuan ini memperkuat hasil penelitian yang dilakukan oleh Astrayani (2017). Hasil penelitian ini mengindikasikan bahwa baik tidaknya sikap para pemimpin keseluruhan tidak ada pengaruhnya terhadap kualitas pelaporan keuangan. Pelaporan keuangan sudah disesuaikan dengan standar pelaporan yang ada karena adanya peran dari pengendalian intern dalam perusahaan.

\section{Pengaruh tingkat pemahaman akuntansi terhadap kualitas pelaporan keuangan} pada usaha bisnis apotek di Kota Denpasar. Hipotesis kedua menyatakan bahwa tingkat pemahaman akuntansi berpengaruh positif terhadap kualitas pelaporan keuangan pada usaha bisnis apotek di Kota Denpasar. Hasil uji regresi menunjukan bahwa variabel tingkat pemahaman akuntansi memiliki nilai koefisien positif sebesar 0,331 dengan nilai signifikansi sebesar 0,043 lebih kecil dari 0,05 sehingga $\mathrm{H}_{2}$ diterima, yang berarti bahwa tingkat pemahamn akuntansi berpengaruh positif terhadap kualitas pelaporan keuangan pada

usaha bisnis apotek di Kota Denpasar. Hasil temuan ini memperkuat hasil penelitian Astrayani (2017) yang mengindikasikan adanya pengaruh positif tingkat pemahaman akuntansi terhadap kualitas pelaporan keuangan. Jika seorang akuntan memiliki pemahaman akuntansi yang tinggi maka kualitas pelaporan keuangan akan meningkat. Pemahaman akuntansi seorang akunting terhadap pembuatan laporan keuangan menunjukan kualitas pelaporan keuangan pada perusahaan tersebut untuk menghindari kekeliruan dan kesalahan dalam pengambilan keputusan laporan keuangan serta bermanfaat bagi pemakai.

Pengaruh fungsi audit internal terhadap kualitas pelaporan keuangan pada usaha bisnis apotek di Kota Denpasar. Hipotesis ketiga menyatakan bahwa fungsi audit internal berpengaruh positif terhadap kualitas pelaporan keuangan pada usaha bisnis apotek 
di Kota Denpasar. Hasil uji regresi menunjukan bahwa variabel fungsi audit internal memiliki nilai koefisien negatif sebesar -0,239 dengan nilai signifikansi sebesar 0,281 lebih besar dari 0,05 sehingga $\mathrm{H}_{3}$ ditolak, yang berarti bahwa fungsi audit internal tidak berpengaruh terhadap kualitas pelaporan keuangan pada usaha bisnis apotek di Kota Denpasar. Hasil temuan ini tidak mendukung temuan dari penelitian sebelumnya yang pernah dilakukan oleh Putra (2013), Diani (2014), Yuliani (2014), Kulsum (2016), Julianty (2016), dan Ranny (2017) yang menyatakan bahwa fungsi audit internal berpengaruh positif terhadap kualitas pelaporan keuangan. Hasil penelitian ini mengindikasikan baik tidaknya fungsi audit internal keseluruhan tidak ada pengaruhnya terhadap kualitas pelaporan keuangan. Pelaporan keuangan yang dibuat sesuai dengan standar pelaporan yang ada karena akunting telah memahami pembuatan dalam laporan keuangan.

\section{SIMPULAN}

Berdasarkan hasil analisis data dan pembahasan hasil penelitian yang telah diuraikan, maka dapat disimpulkan sebagai berikut:

1) Etika kepemimpinan tidak berpengaruh terhadap kualitas pelaporan keuangan pada usaha bisnis apotek di Kota Denpasar.

2) Tingkat pemahaman akuntansi berpengaruh positif terhadap kualitas pelaporan keuangan pada usaha bisnis apotek di Kota Denpasar.

3) Fungsi audit internal tidak berpengaruh terhadap kualitas pelaporan keuangan pada usaha bisnis apotek di Kota Denpasar. 


\section{DAFTAR PUSTAKA}

Arel, B., Beaudoin, C.A., Dan Cianci, A.M. 2012. The Impact Of Ethical Leadership And The Internal Audit Function. Journal Of Business Ethics, Vol 109, No. 3, Pp. 351-366

Astrayani. 2017. Pengaruh Etika Kepemimpinan, Fungsi Badan Pengawas Dan Tingkat Pemahaman Akuntansi Terhadap Kualitas Pelaporan Keuangan (Studi Kasus Pada LPD Di Kecamatan Abiansemal). Skripsi. FE Universitas Mahasaraswati Denpasar.

Baridwan, Zaki. 2004. Intermediate Accounting "Pengantar Akuntansi", Buku 2, Edisi 21, Salemba Empat. Jakarta

Diani, Dian Irma. 2014. Pengaruh Pemahaman Akuntansi, Pemanfaatan Sistem Informasi Akuntansi Keuangan Daerah Dan Peran Internal Audit Terhadap Kualitas Laporan Keuangan Pemerintah Daerah (Studi Empiris Pada Satuan Kerja Perangkat Daerah Di Kota Pariman). Skripsi. Universitas Negeri Padang.

Hasibuan, Malayu S.P. 2009. Manajemen Dasar, Pengertian Dan Masalah. Jakarta: PT Bumi Aksana.

Iswara, Ulfah Setia. 2013. Faktor-Faktor Yang Mempengaruhi Kualitas Pelaporan Keuangan Usaha Menengah Kabupaten Jember. Skripsi. FE Universitas Jember.

Kepmenkes Nomor 1027/Menkes/SK/IX/2004 Tentang Standar Pelayanan Kefarmasian Di Apotek.

Keputusan Menteri kesehatan RI Nomor 1332/Menkes/SK/X/2002 Tentang Pencabutan SIA.

Meilani Purwanti., Wasman, Wasman. 2014. Pengaruh Pemahaman Akuntansi, Pemanfaatan SIA Dan Peran Internal Audit Terhadap Kualitas Laporan Keuangan (Survei Pada Koperasi Pegawai Republik Indonesia Kota Bandung). Jurnal Bisnis Dan Manajemen Vol. 4, No. 3.

Mulyadi. 2013. Auditing. Jilid 2. Edisi Keenam. Jakarta: Selemba Empat.

Nudilah. 2016. Pengaruh Etika Kepemimpian, Fungsi Badan Pengawas Dan Tingkat Pemahaman Akuntansi Terhadap Kualitas Pelaporan Keuangan Pada Lembaga Pengkreditan Desa Di Kota Denpasar. Skripsi. Universitas Mahasaraswati Denpasar.

Peraturan Menteri Kesehatan Nomor 922/Menkes/PER/X/1993 Tentang Cara Pemberian Izin Apotek.

PP Nomor 51 tahun 2009 Tentang Tugas dan Fungsi Apotek.

Putra, Nashir Yudha. 2014. Pengaruh Etika Kepemimpinan Dan Fungsi Audit Internal Terhadap Pengambilan Keputusan Pelaporan Keuangan Pada Perusahaan Manufaktur Di Semarang. Skripsi. FE Universitas Semarang.

Rifa, I., bachtiar, A. 2014. Pengaruh Etika, Kompetensi, Dan Pengalaman Dalam Mengelola Barang Milik Negara Terhadap Kualitas Laporan Keuangan Pemerintah Pusat (Survei Pada Badan Pertahanan Nasional Republik Indonesia Di Lingkungan Provinsi Daerah Istimewa Yogyakarta). Skripsi. Fakultas Ekonomi Universitas Negeri Yokyakarta. 
Robbins, Stephen. P. 2006. Perilaku organisasi. Edisi Bahasa Indonesia. Indeks Kelompok Gramedia. Jakarta.

Suryandari, Ni Nyoman Ayu dan Novitasari, Ni Luh Gde. 2016. Sistem Pengendalian Intern Pada Koperasi Se-Bali. Jurnal Sosial dan Humaniora. Volume 5 No 2 Oktober 2016. Universitas Pendidikan Ganesha.

Umar, M. 2000. Manajemen Apotek Praktis. Jakarta Pusat.

Widyawati, A. 2012. Konstruksi Sosial Intelellectual Capital: Studi Interpretif Atas Keberadaan Intellectual Capital Dan Pengungkapannya Pada Bank Jateng.

Windiastuti, Ruri. 2013. Pengaruh Sumber Daya Manusia Bidang Akuntansi Dan Sistem Pengendalian Internal Terhadap Kualitas Laporan Keuangan Pemerintah Daerah (Studi Kasus Pada DPPKAD Kota Bandung). Skripsi Universitas Widyatama: Bandung. 